\title{
A comunicação no processo de supervisão EM ENFERMAGEM
}

\author{
Maria de Lourdes Rodrigues*
}

\begin{tabular}{l|l|} 
& $\mathrm{RBEn} / \mathbf{1 1}$ \\
\hline
\end{tabular}

RODRIGUJs, M.L. - A comunicaçāo no processo de Supervisāo de Enfermagem. Rev. Bras. Enf.; DF, 29 : 91-96, 1976.

\section{INTRODUÇAO}

O Grupo de Trabalho designado pelo Secretário da Saúde do Estado de São Paulo em 1974, para fazer um levantamento preliminar das condiçōes de vigência da Reforma da Secretaria de Estado da Saúde, implantada em 1969, elaborou um "Documento de Avaliação Crítica" que apontou 7 (sete) áreas problemáticas, entre as quais incluia a supervisão.

Em decorrência deste levantamento preliminar, no início de 1975, foram criados grupos de estudo das áreas criticas (GEACs), entre eles estando o que se encarregou de estudar o problema da supervisão, GEAC-7.

Do referido Documento, este GEAC selecionou alguns itens que Julgou representativos das dificuldades que interferiam basicamente no processo de implantação da supervisão na Secretaria da Saúde; destes itens destacou um que interessa especificamente ao assunto de que vamos tratar e que diz o seguinte:
“- inexistência de programas de saúde, agravada pela falta absoluta de um sistema de informação".

A análise deste aspecto da supervisão evidenciou sua extensão e gravidade, e salientou os seguintes problemas, direta ou indiretamente ligados à comunicação:

- falta de estruturação adequada dos órgãos técnicos, de modo a precisar as funçōes e seus agentes e 0 esclarecimento do seu processo;

- insuficiência de pessoal, acarretando acúmulo de funçōes para alguns funclonários, estancamento de funçōes e ações, bloqueio ou ausência de comunicação;

- Inexistência de mecanismos oficials de coordenação entre órgãos normativos e executivos, dificultando o conhecimento e uso das fontes de comunicação;

- Inexistência de sistematização no fluxo de comunicação;

- conhecimento inadequado (inexisten-

* Docente da Disc. Enfermagem de Saúde Pública da Faculdade de Saúde Pública da USP. 
RODRIGUES, M.L. - A comunicação no processo de Supervisão de Enfermagem. Rev. Bras. Enf.; DF, 29 : 91-96, 1976.

te, insuficiente ou errôneo) do processo de comunicação em supervisão;

- desatualização e falta de padronização dos modelos usáveis na comunicação em supervisão.

De acordo com o que se tem observado em relação aos problemas da supervisão, presumimos que estes são freqüentes $\mathrm{e}$ comuns à Secretaria da Saúde e a outras instituiçōes de saúde do próprio Estado de São Paulo, como também de outros Estados do País.

Assim sendo, achamos conveniente relacionar, neste estudo, o assunto "Comu" nicação" à Supervisão, com a finalidade de contribuir para a identificação, esclarecimento ou conhecimento de alguns elementos da comunicação relacionados ao processo de supervisão.

\section{OBJETIVOS DO ESTUDO DA COMUNICAÇAO EM SUPERVISAO:}

1. Contribuir para identificar os dados (informes), que devem ser colhidos e transmitidos em supervisão

2. Contribuir para esclarecer:

2.1 onde (fontes) estes dados podem ser levantados

2.2 quais meios (instrumentos) podem ser usados;

2.3 por que meios (canais) devem ser veiculados;

2.4 que linha administrativa (fluxo) devem seguir os informes.

\section{COMUNICAÇAO - ALGUMAS CONSIDERAÇOESS SOBRE SEU SIGNIFICADO E SEU PROCESSO}

A fim de que possamos estabelecer uma base de entendimento mútuo na linguagem que vamos empregar, recordaremos algumas noçōes essenciais sobre supervisão e comunicação.

A definição de supervisão sobre a qual nos basearemos aqui, diz que "Supervisão é a função administrativa que consiste num conjunto de atividades, cuja finalidade é contribuir para que as açōes planejadas sejam executadas de acordo com as normas determinadas pela instituição.

Seu processo envolve incentivo orientação e ajuda ao pessoal, com base em suas necessidades e com a plena utilização de suas potencialidades".

Para que os supervisores possam cumprir sua função, foi salientado que, necessariamente, devem adotar o processo pessoal de comunicação, o intercâmbio de idéias pessoa a pessoa.

Desta definição vamos destacar algumas expressōes que nos parecem importantes sob o ponto de vista da comunicação, sendo elas:

- atividades, açōes planejadas e executadas de acordo com normas

- contribuir

- incentivo, orientação e ajuda

- plena utilização de potencialidades.

Em resumo, queremos salientar que certas açð̋es de saúde são planejadas; que há pessoas responsáveis, entre elas os supervisores, para que as mesmas sejam executadas de acordo com as normas; que estas pessoas, sendo responsáveis perante outras, devem portanto, prestar contas - dar informes - quanto ao dever de utilizar plenamente o potencial do pessoal, por meio de incentivo, orientação e ajuda, contribuindo assim para que se$\mathrm{ja}(\mathrm{m})$ atingido $\mathrm{o}(\mathrm{s})$ objetivo(s), propostos pela instituição. Para isto, esses responsáveis devem, por sua vez, colher e veicular informes.

Como se vê, os supervisores estão continuamente envolvidos num processo de comunicação.

O que é para nós comunicação?

Aceitamos a definição de Lee Thayer, que diz ser a comunicação "uma função vital, por meio da qual indivíduos e organizaçōes se relacionam uns com os outros, com o meio ambiente e com as pró- 
RODRIGUES, M.L. - A comunicaçāo no processo de Supervisāo de Enfermagem. Rev. Bras. Enf.; DF, 29 : 91-96, 1976.

prias partes, influenciando-se mutuamente, transformando fatos em informaçōes".

A comunicação tem sido representada esquematicamente da forma como se sabe:

$\mathrm{A}<\longrightarrow \mathrm{M}<\longrightarrow \mathrm{B}=\mathrm{X}$, onde $\mathbf{A}=$ a fonte, ou comunicador, ou emissor que codifica idéias e as envia por $<\longrightarrow=$ canais bidirecionais, em forma de

$\mathbf{M}=$ mensagens, dados, informes ou fatos que são veiculados para

$\mathbf{B}=$ receptor, que descodifica as mensagens, interpreta-as, transformando-as, em

$\mathrm{X}=$ informaçōes, $\mathbf{0}$ produto final da comunicação.

Estes elementos estão presentes, quer a comunicação seja intrapessoal ou interpessoal, direta ou indireta.

A finalidade da comunicação, nas várias modalidades, será sempre a de atingir o estado de coisas pretendido ou determinar o estado de coisas aparente, podendo ser invertida esta ordem, conforme o interesse do indivíduo ou da organização.

Porém, em qualquer dos casos, é preciso ressaltar que, o que sai da fonte emissora são sempre dados, informes, ou fatos e nunca a informação acabada; esta é feita ao nível pessoal dentro de cada individuo que recebe o informe, 0 interpreta e transforma em informação.

Lembremo-nos de que o comportamento ou atitude manifesta do individuo pode estar ou não coincidindo com sua atitude latente, na base da qual estão seus conhecimentos, valores e sentimentos. Ora, o comportamento subseqüente do receptor num processo de comunicação, é o que vai indicar se e como ele recebeu e interpretou a mensagem e se a informaçã̉o que ele elaborou evidencia o(s) conhecimento(s), $o(s)$ valor(es) e $o(s)$ sentimento(s) que os dados originais emitidos pretendiam ocasionar.
Afirma-se, contudo, que não há sequer duas informaçōes idênticas; o que há é um bom ou um mau condicionamento dos individuos para se compreenderem e se aceitarem, abstraindo as pequenas alteraçōes de interpretação de tal forma que, no conjunto, pode haver uma aparência razoável de uniformidade.

Considera-se, entretanto, que houve comunicação quando houver indicação de que houve recebimento e interpretação de dados; conseqüentemente, conclui-se que a comunicação pode ter sido bloqueada isto é, não se deu, ou pode ter sido realizada correta ou erroneamente.

Qualquer obstáculo em qualquer dos elementos que constituem um processo de comunicação pode dificultá-lo ou mesmo impedí-1o; em forma codificada a fonte emite dados que podem ou não sofrer alteraçōes ao longo do processo, alteraçōes estas que podem ser motivadas:

- pelo próprio emissor (mal informado, inábil, bloqueado, etc.) ;

- pelos instrumentos (insuficientes, desconhecidos, errôneos) ;

- pelos canais de veiculação (inadequados) ;

- pela mensagem (obscura, complicada, inadequada) ;

- pelo receptor (desatento, desinteressado, incapaz).

Evidentemente está clara a importância que estes fatos apresentam em supervisão; daí a atenção que se deve dar para se estabelecer condiçōes adequadas que permitam a realização da comunicação interpessoal nesta função administrativa; estas condiçōes podem ser esquematizadas como segue:

- garantir a existência de estruturas (administrativa, funcional, etc) bem definidas e racionadas;

- estabelecer regrás para o funcionamento da instituição;

- determinar, distribui e delimitar as açōes e funçōes; 
RODRIGUEs, M.L. - A comunicação no processo de Supervisāo de Enfermagem. Rev. Bras. En?.; DF, 29 : 91-96, 1976.

- normalizar o processo de comunicação:

- o que se comunica;

- quem adquire e transmite dados;

- onde e quando se adquirem e se transmitem dados e por que melos;

- com que conseqüências previsiveis.

\section{IV - ELEMENTOS CONSTITUINTES DO PROCESSO DE COMUNICAÇAO}

Consideremos agora, separadamente, os diversos elementos do processo da comunicação, sob o ponto de vista da supervisão.

1. Dados emitidos no processo de comunicação na função supervisora

O que se comunica em supervisão?

Como em todo processo de comunicação, o que sal da fonte emissora são sempre dados. Em supervisão estes dados podem ser:

- informes dos órgãos reguladores das açōes e operaçōes a serem desempenhadas dentro da organização, isto é:

- normas e procedimentos

- planos, programas e projetos

- ordens de serviço originais ou velculadas

- informes sobre a produção dos órgãos executores das açōes a saber:

- dados de unidades de produção qualitativa e quantitativa de atividades "melo" e "fim", diários mensais ou anuais, em forma de boletins ou relatórios estatísticos;

- dados de produção consolidados de unidades locais (CS e DS) e regionais;

- dados de fichas funcionais do pessoal;

- dados de fichas de usuários dos serviços;

- dados de relatórios descritivos;

- informes sobre problemas ligados ao processo regulador das açōes, ou às condiçōes de execução dos serviços, ou pessoal nos diversos escalöes da organização.

Como estes dados servem para alimentar o sistema de supervisão e no seu retorno, realimentá-lo, devem obedecer a certas condiçōes para se evitar que, a partir deles, a comunicação possa apresentar problemas. As normas que regem sua elaboração devem prever que sejam teitos de modo claro, tão simples quanto possivel e que atendam as finalidades $e$ os objetivos previamente traçados. Se estas condiçōes não forem observadas, os dados podem ser mal interpretados ou mesmo não se conseguir descodificá-los, além de se consumir tempo e recursos sem atingir nenhum objetivo.

\section{Fonte(s) emissora(s) dos dados acima} citados

Desde que se aceite a comunicação como um intercâmbio de idéias ou dados, entre o(s) emissor(es) e um ou mais receptores, pode-se considerar na comunicação a existência de fontes nos dois extremos do processo ( $A$ e B).

De acordo com esta idéia, se a função supervisora, numa instituiçāo, for sistematizada pode-se considerar como fontes de comunicação, todas as unidades ou setores em que houver agentes de qualquer atividade que se relacione com a supervisão, pois aí se identificam açōes que vão desde a emissão de dados sobre "o que" "como" e "quando fazer", etc, até a emissão de infomes sobre a produção realizada. As fontes corresponderiam, pois, aos diversos níveis da organização estrutural, podendo assim, serem identificadas:

a. fontes do nível central;

b. fontes do nível de departamentos, divisōes regionais, etc.

c. fontes do nível de seçōes, distritos sanitários, etc.

d. fontes do nível de clínicas, unidades locais, etc. 
RODRIGUEs, M.L. - A comunicaçăo no processo de Bupervisāo de Finfermagem. Rev. Bras. Enf.; DF, 29 : 91-96, 1976.

Para que não surjam problemas atribuíveis às fontes de comunicação, são feitas as seguintes recomendações:

- que as bases apontadas anteriormen-

te como essenciais num processo adequado de comunicação sejam consideradas e efetivadas;

- que o comunicador, em qualquer ponto da estrutura, esteja bem informado:

- tenha recebido preparo prévio profissional e institucional requeridos;

- mantenha-se atualizado nos seus afazeres;

- possua as qualidades pessoais preconizadas; especialmente as necessárias para relacionar-se bem.

3. Instrumentos usáveis em comunicação na função supervisora

O principal instrumento para a realização da supervisão é a comunicação direta, verbal, pessoal, por melo de entrevistas e reuniōes. A direta, telefônica, reserva-se para casos urgentes e/ou imprevistos.

A comunicação indireta, escrita, poderá ser utilizada quando indicada, realizando-se por meio de instrumentos que variam de acordo com o nivel em que são usados e são a seguir detalhados:

a. a nível central:

- resoluções;

- regulamentos;

- portarias;

- manuais de procedimentos;

- normas;

- planos, programas, projetos;

- ordens de serviço;

- ofícios;

- circulares;

- memorandos;

- relatórios descritivos e/ou estatísticos;

- fichas funcionais do pessoal deste nível. b. a nivel de departamentos, divisões regionais, etc.

- programas, projetos;

- ordens de serviço;

- ofícios;

- circulares;

- memorandos;

- relatórios descritivos e/ou estatísticos;

- fichas funcionais do pessoal deste nível.

c. a nível de secções, distritos sanitários, etc.

- projetos;

- ordens de serviço;

- ofícios;

- circulares;

- memorandos;

- relatórios descritivos e/ou estatísticos;

- fichas funcionais do pessoal deste nivel;

d. a nível de clínicas, unidades locais, etc.:

- circulares;

- memorandos;

- fichas funcionais do pessoal deste nível;

- fichas de registros das atividades fins e melo;

- boletins de serviço;

- relatórios estatísticos e/ou descritivos.

Se os instrumentos usáveis em supervisão não forem racionalmente planejados, suficientemente conhecidos, adequadamente preenchidos e arquivados, não cumprirão sua finalidade que é a de possibilitarem a boa comunicação e o fornecimento de material para as organizações e indivíduos responsáveis pelas ações decisórias; daí se recomendar que estas 
RODRIGUES, M.L. - A comunicaçāo no processo de Supervisão de Enfermagem. Rev. Bras. Enf.; DF, 29 : 91-96, 1976.

qualidades sejam regulamentadas e observadas.

4. Canais por onde se velcula a comunicação na função Supervisora

Quando a comunicação se fizer diretamente, o canal é o entendimento $v$ erbal falado; as disposições legais que 0 possibilitem devem estar previstas e regulamentadas nas normas de serviço.

Para a transmissão do incentivo, orientação e ajuda pessoais, várias técnicas e canais podem ser usados, desde a entrevista, em que se faz uma exposição explicativa, uma demonstração, um levantamento de situação, uma análise de problemas, uma avaliação de produção, etc., até à discussão de grupo para solução de problemas e a reunião, em que as mesmas atividades referidas acima podem ser realizadas para se atingir um grupo maior ou ainda para se expor 0 resultado da supervisão.

Quando o entendimento for indireto, por comunicação escrita, esta deve fluir através dos canais competentes, obedecendo a linha de comunicação legal nos vários escalōes da estrutura.

Se se usarem canais não indicados ou forem usados inadequadamente, a comunicação corre o risco de ser bloqueada, mal interpretada ou desvirtuada.

Tanto na utilização dos instrumentos, como no uso dos canais competentes, deve-se ter sempre em mente o receptor para quem a mensagem é enviada. Não é demais enfatizar que a infomação é completada ao nível do intelecto do receptor e, assim sendo devem-se observar algumas recomendaçōes:

- considerar os princípios do processo ensino/aprendizagem especialmente os que se referem a:

- que a aprendizagem é um processo individualizado, portanto, pode haver diferenças de percepção;

- que o educando deve estar motivado, do contrário seu desinteresse pode torná-lo desatento e não haver captação das mensagens;

- que o ensino deve ser integrador e tender para o perfeito, de modo a evitar e ajustar interpretações errôneas e, conseqüentemente, informações incorretas que geram execuções indevidas e frustraçōes;

- que todos podem aprender, portanto, a mensagem deve atingir a todos; se "algum discípulo não aprendeu, é que o nestre não soube ensinar". As técnicas de transmissão devem ser adaptadas à capacidade de aprendizagem dos receptores.

5. Fluxos da comunicação na função supervisora

Se se considerar a comunicação um processo em que os dois extremos podem ser fontes de emissão de dados, o fluxo dos informes terá sempre duas direções:

- no relacionamento interpessoal num mesmo nível seria um fluxo horizontal, de ida e volta de informes ou

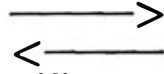

ou $<\longrightarrow$, e o que se verifica por exemplo entre as seções de um mesmo departamento, num grupo de trabalho, etc.

- no relacionamento entre níveis diferentes, o fluxo seria em linha vertical, descendente e/ou ascendente, como se dá entre os órgãos centrais normativos de supervisão e os órgãos regionais e 10cals executivos.

Ambos, o relacionamento horizontal e o vertical, devem estar também previstos e regulamentados nas normas de serviço. de se salientar que, na comunicação em linha vertical, nenhum nível deve ser abstraído no fluxo de informes, do contrário, a comunicação poderá ser invalidada, ou pelo menos impugnada, podendo haver, também, em decorrência do fato, obstáculos nas demarches para solução de problemas ou efetivação de medidas necessárias à execução do trabalho. 